\title{
What does the Nom say? An algorithm for case disambiguation in Hungarian
}

\author{
Noémi Ligeti-Nagy \\ MTA-PPKE \\ Hungarian Language Technology Research Group \\ ligeti-nagy .noemi@itk.ppke.hu \\ Andrea Dömötör \\ MTA-PPKE \\ Hungarian Language Technology Research Group \\ domotor.andrea@itk.ppke.hu \\ Noémi Vadász \\ Research Institute for Linguistics \\ Hungarian Academy of Sciences \\ vadasz.noemi@nytud.mta.hu
}

\begin{abstract}
In this paper, we present our algorithm called nom-or-not designed for dissolving case-disambiguation in Hungarian. By case, we mean an abstract syntactic case, a kind of syntactic role of the given token. Nouns and proper names, adjectives, participles and numerals without a case suffix are always tagged as Nom, although the lack of case ending may represent various functions: it may mark the subject of the sentence or a possessor or the nominal part of a nominal predicate or the vocative case; on top of that, a modifier of a nominal or a nominal combined with a postposition lacks a case suffix as well; proper names consisting of two or more elements are also caseless. Our algorithm is motivated by the needs of a psycholinguistically motivated parser which aims to process sentences from left to right. Therefore, our case disambiguator follows the basic principles of the parser and analyses the sentences from left to right, always making a decision based on the information of the previously processed elements and the elements in a two token wide look-ahead parsing window. Our preliminary results show that if some modifications and new rules are added and it's run on a more precisely annotated corpus, it can improve the disambiguator algorithm. The preliminary results were obtained from a manually annotated corpora of 500 sentences.
\end{abstract}

This work is licensed under a Creative Commons Attribution 4.0 International Licence. Licence details: http://creativecommons.org/licenses/by/4.0/ 


\section{Kivonat}

Tanulmányunkban bemutatjuk a nom-or-not névre keresztelt algoritmust, amely az esetrag nélküli névszók mondatbeli szerepének egyértelműsítését végzi. A magyarban a testes esetrag hiánya nem egyértelműen a nominatívuszi esetet kódolja; egy testes esetragot magán nem viselő névszó többféle szerepet betölthet a mondatban: lehet valóban alany, lehet birtokos, lehet névszói állítmány névszói része, lehet névszó módosítója vagy névutó előtt álló névszói elem, lehet vokatívuszi esetben álló névszó, vagy lehet több elemből álló tulajdonnév egyik belső eleme. Algoritmusunk háttere egy az emberi szövegfeldolgozást modellálni szándékozó elemzőrendszer. Ennek szellemében az eset-egyértelműsítést az elemzőrendszer működési elvei alapján végezzük: balról jobbra haladva dolgozzuk fel a szöveget, mindig csak az eddig már olvasott szavakon, illetve a kételemű, előretekintő elemzési ablakban látható információra támaszkodva. Szabályalapú algoritmusunkat egy 500 mondatból álló korpuszon értékeljük ki, melyben kézzel annotálunk minden testes esetrag nélküli névszót. Eredményeink azt mutatják, hogy eljárásunk - két előzmény-algoritmusához hasonlóan, melyek egy-egy részfeladat kezelésére születtek - pontossága néhány szabály beillesztésével és pontosabban annotált korpusz használatával könnyedén javítható lehet.

\section{Introduction}

Here we present a rule-based algorithm offering a case disambiguation method designed primarily for the ANAGramma parsing system (Prószéky and Indig, 2015; Prószéky et al., 2016). Following a brief description of the parsing system and its principles we turn to the discussion of the possible functions of nominals in the sentence and finally we introduce our algorithm disambiguating caseless nominals in Hungarian sentences.

The current algorithm is an upgraded and extended version of two previously described algorithms presented in Ligeti-Nagy et al. (2018) and Dömötör (2018), to be described in details below.

It is inevitable to clarify some terminological questions. Throughout this article, by nominals we mean nouns, adjectives, participles and numerals - words able to fill the role of a subject or a possessor, words that may be modifiers of another nominal etc. This also applies to pronouns that substitute these lexical word classes.

With case, and more specifically, with function in the sentence on the one hand we refer to the set of syntactic roles in the sentence, on the other hand we use function in the sentence to identify nominal positions inside a noun phrase (NP) as well. Therefore, when we aim to specify the function of a caseless nominal in the sentence, we want to determine if it is the argument of a verb. Otherwise we specify its role inside an NP.

\section{Background}

Our algorithm fits into the frame of ANAGramma, a psycholinguistically motivated parsing system which tries to model human sentence processing with its left-to-right and word-by-word parsing design. The context of a word often influences its interpretation, therefore ANAGRAMMA uses a two token wide look-ahead window that provides information of the right context of the word, while the information of the 
previously processed elements is always available in the so-called pool. The theoretical background of ANAGRAMMA is based on a two-phased sentence processing model, the Sausage Machine where the parsing process consists of two main phases. The first phase is - as Frazier and Fodor (Frazier and Fodor (1978)) calls it - the Preliminary Phrase Packager which assigns the lexical and phrasal nodes to groups of words within the string input. The look-ahead window of ANAGramma implements this first phase. In this phase the components of the sentence are prepared, e.g. disambiguation of case-ambiguous nominals presented in this paper. Then, in the second phase, these packaged phrases get their roles in the sentence by adding non-terminal nodes. The second phase is called the Sentence Structure Supervisor, as the packages the pieces of the sausage - receive their role in the sentence.

\subsection{Caseless nominals in Hungarian}

Our basic assumption about caseless nominals is that their function in a sentence may be one of the followings: subject (1a), unmarked possessor $(1 \mathrm{~b})$, argument of a postposition 1 (1c), element in vocative case (where the noun or the pronoun is used to address a person directly, (1d)), modifier of another nominal (1e), part of a proper name consisting of more than one component (1fi) or part of a nominal predicate (discussed in detail later). In the examples (1a)-(1f), the third row illustrates the current morphological annotation of the words.

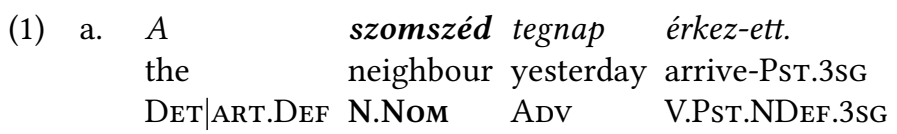

'The neighbour arrived yesterday'

b. A szomszéd kutyá-ja ugat.

the neighbour dog-Poss.3sg bark.3sg

Det|art.Def N.Nom N.Poss.3Sg.Nom V.Prs.NDef.3sg

'The neighbour's dog barks.'

c. A szomszéd után érkez-t-ünk.

the neighbour after arrive-PST-1PL

Det|ARt.Def N.Nom Post V.Prs.NDef.1sg

'We arrived after the neighbour.'

d. fó reggel-t, szomszéd!

good morning-Acc neighbour

Adj.Nom N.Acc N.Nom

'Good morning, neighbour!'

e. Az elözö szomszéd kedves volt.

the previous neighbour kind be.Pst.3sg

Det|ARt.Def Adj.Nom N.Nom Adj.Nom V.Pst.NDef.3sg

'The previous neighbour was kind.'

\footnotetext{
${ }^{1}$ Considering the noun to be the argument of the postposition is a simplification and is motivated by AnaGramma being a dependency-parser. In our system, the noun is a dependent of the postposition. A detailed argument for this, however, is beyond the scope of this paper.
} 
f. Máris szomszéd tegnap érkez-ett.

Máris neighbour yesterday arrive-Pst.3sg

N.Nom N.Nom Adv V.Pst.NDEF.3sg

'Neighbour Máris arrived yesterday.'

As mentioned above, the emphasised nominals in (1a)-(1fif) are either arguments of the verb or parts of an NP. The role of predicative nominals, however, is different. Sentence parsing in computational linguistics is usually based on the verb and its argument frame. However, in Hungarian, it is possible to make well-formed, complete and non-elliptic sentences without a finite verb. This is due to the so-called zero copula phenomenon. The copula in Hungarian can be defined as 'an expletive' which is present "if and only if its presence is required by a morphophonological constraint" (É. Kiss (2002):72). This morphophonological constraint is related to the Third Person Parameter of Stassen (1994) which means that the (verbal) copula can only be omitted in the third person in present tense. See examples in (2).

(2)
a. A szomszéd-om ügyvéd.
the neighbour-Poss.1sg lawyer
'My neighbour is a lawyer.'
b. A szomszéd-om ügyvéd volt.
the neighbour-Poss.1sg lawyer be.Pst.3sg
'My neighbour was a lawyer.'
c. Ügyvéd vagyok.
lawyer be.1sG
'I am a lawyer.'

In nominal sentences like (2a) the parsing tool needs to be able to identify whether or not the sentence contains a nominal predicate as the nominal this should be the head of the whole sentence.

Predicative nominals can be nouns, adjectives, occasionally numerals, and pronouns that substitute these elements. If the predicate is a noun phrase, then the nominal, which is the head of the phrase, is considered predicative. According to Higgins (1973) and others there are various types of copular clauses. The two main categories are predicative and equative sentences. By the former one, we mean those copular sentences in which the nominal predicate is a bare noun or adjective, an indefinite noun phrase or adjectival phrase which denotes an attribute of the subject. In contrast, the latter sentence type states the equality of two individuals. In this case, both the predicate and the subject must be a referential, therefore a determiner phrase (DP) - which encodes definiteness in Hungarian. DPs can be NPs with definite article, proper names or possessive NPs.

The predicative nominal is morphologically unmarked in both types of copular sentences, therefore it shows no difference in form to nominative, genitive and caseless nominals mentioned above. The issue of the case of predicative nominals could be subject of theoretical debate. There are three main approaches to this question. We could either 1) assume a phonologically zero predicative nominal, 2) claim that the nominal predicate is nominative which gets its case by the agreement with its subject (Szécsényi, 2000), or 3) simply consider it caseless. This study does not intend 
to take sides in this issue. With respect to automatic parsing, we may consider the predicative role as a functional feature indicating that the nominal in question needs a subject and optionally a copula as complement. The question of abstract cases does not have special importance for our purposes, therefore in the following, predicative nominals will simply be considered nominals with predicative feature and without case marking.

Based on the above described roles it can be stated that caseless nominals either bear a phonologically zero case suffix (when functioning as a subject as in (1a), an unmarked possessor (1b) or being in vocative case (1d)) or bearing nothing (when modifying another nominal (1e), being followed by a postposition (1c), being part of a complex proper name (1f), or functioning as a predicative nominal (2)).

Throughout this paper the following annotation is used to distinguish the previously detailed functions:

- phonologically zero case suffix (marking either a Nom or a Gen): $\alpha$

- real 'caselessness' (marking the true lack of case ending): 0

- tag marking the predicative nominal: Pred

- Nom, Gen, and Voc stands for the nominative, genitive, and vocative case, respectively

\subsection{Previous algorithms}

nom-or-what presented in (Ligeti-Nagy et al., 2018) is a rule-based algorithm primarily built on the ideas drawn up in (Vadász and Indig, 2018) where a basic method was introduced to identify unmarked possessors in a sentence (nomorgen). nom-or-what aims to identify the roles of caseless nominals in the sentence solely based on the information seen in the two token wide look-ahead window and was essentially planned to be a module of the ANAGramma parser. This algorithm does not disambiguate nouns in vocative case and only operates on sentences with a verb present (meaning that it does not intend to identify nominal predicates). The algorithm was designed by analysing the caseless nominals both inside and in the final position of an NP in a syntactically annotated corpus of Hungarian (Szeged Treebank 2.0, Csendes et al. (2005)).

Three sets of rules were created for nouns, adjectives, and numerals. The rules attempt to define the precise role of the token under examination based on its morphological annotation and on the information gained from the parsing window. If no solid decision can be made and more information is needed to further specify an element, default tags were used. The performance of the algorithm was evaluated on a manually annotated corpus of 500 sentences collected from the Hungarian Gigaword Corpus (Oravecz et al., 2014). The high precision (97.73\%) indicated that the basic principles of the algorithm are correct. The relatively low recall $(67.63 \%)$ was explained by the authors as a sign of the excessive use of default values.

The algorithm described in Dömötör (2018) (named is-pred) was also designed to constitute a part of the ANAGRAMmA parser. It follows the principles of the sausage machine model described in section 2. nom-or-what was basically the implementation of the first phase of this two-phased parsing model. The second phase carried out by is-pred uses the whole left context, the so-called pool. Besides, the is-pred algorithm strongly relies on the output of nom-or-what, as there would be little chance 
to identify predicative nominals based exclusively on the left context without taking into account the local decisions of the first phase.

In sum, the input of is-pred is a sequence that consists of the nominal in question and the part of the sentence that precedes it. The left context of the current word is already analysed and disambiguated by nom-or-what (if possible), thus the algorithm can use various pieces of morphosyntactic information from the pool. The output is a value, similar to trivalent logic: Pred if the nominal is obviously a predicate, Nonpred if it is obviously not a predicate, and Undefined if its syntactic role is still unclear from the given information.

The is-pred algorithm achieved high precision on its test, however, it has some deficiencies that should be improved. On the one hand, its responses are binary which do not complete the analysis in the Nonpred cases. On the other hand, is-pred only handles the predicative copular clauses, therefore the recognition of nominal predicates in equative sentences is a significant gap that this study intends to fill.

The idea behind the current algorithm - called nom-or-not, referring to its role as a synthesis of its antecedents - is, on the one hand, to merge all working and tested rules of the previous algorithms, and, on the other hand, to fill as many gaps left as possible.

\section{Method}

The method of nom-or-not follows nom-or-what and is-pred in being rule-based which means that the algorithm does not use machine learning approaches rather it is built on linguistically grounded, hand-crafted rules. The main difference among the three is that nom-or-not merges the two phases of parsing and aims to disambiguate each possible role of caseless nominals in one step. For this task, it is necessary to use both the window and the pool at the same time, therefore the algorithm operates with both forward- and back-looking rules. In either case, the principal source of information is the morphological annotation with only a small scent of lexical information. That is, the disambiguation of caseless nominals is carried out primarily based on the syntactic structure.

The algorithm is designed to process sentences annotated by the emMorph morphological analyser (Novák (2003), Novák (2014), Novák et al. (2016)), where the token, the lemma and the morphological tags are separated by a /, and the morphological tags are in square brackets (USA/USA/[/N][NOM]). The algorithm processes the sentences from left to right, word by word. The rules are only applied if the token under examination is tagged as Nom. As the targeted parsing method has a psycholinguistic motivation, the case disambiguation algorithm first gathers all the information of the given nominal that is deductible from the pool (the collection of the information of the already processed elements). The back-looking rules are used for preliminary disambiguation of predicative nominals, and they are the following:

- If there is a non-copular finite verb in the pool $\rightarrow$ the current token is not Pred

- If there is a nominative in the pool $\rightarrow$ the current token is Pred, if other cases will be ruled out based on the window, and only Nom and Pred remains as an option

- If the word is the possible head of a DP and there is no nominative in the pool $\rightarrow$ it is not Pred 
- If proper name $\rightarrow$ Head of DP

- If possessive $\rightarrow$ Head of DP

- If preceded by a determiner and optionally one or more NP-modifiers $\rightarrow$ Head of DP

- If demonstrative pronoun ('this', 'that') $\rightarrow$ Head of DP

The rule to detect vocative case on nominals is rather simple at the moment: if the pool contains a verb in 1st or 2nd person singular or plural, and now we see a 3rd person singular or plural noun assigned nominative case Nom (see example (3), where the morphological annotation of the words can be seen in the third line), then it is a Voc.
(3) Jövök, apám!
come.Prs1Sg father.Poss3Sg [/V][Prs.NDef.1Sg] [/N][Nom]

I'm coming, father!

Having exploited the left context the algorithm refines its judgment about the nominal in question using the information gathered from the window. The forwardlooking rules are displayed in decision trees in Figures 1-3. Obviously, only those branches will be activated that are relevant considering the conclusions drawn up from the information coming from the pool; and every non-final decision is finalised if the knowledge based on the pool makes it possible to rule out a part of the outcome. (E.g. an edge leads us to a leaf with the tag nom_or_pred on it, but the pool already made it clear that the actual token cannot be a Pred, therefore here the tag Nom will be assigned to this token.)

As the algorithm does not exploit the whole sentence, there necessarily may remain cases where no certain decision can be made. We use the following tags for these cases:

- $\alpha$ : this is the default case of nouns; if no final tag can be assigned to a noun, but the predicative function is ruled out, the token in question is marked with an $\alpha$, which can later be further specified as Nom or Gen

- Nom/Pred: a tag signaling that the given word may either be the subject of the sentence or the nominal predicate

- 0/Pred: a tag signaling that the given word may either be a modifier element in an NP or the nominal predicate of the sentence

We assume that nouns and proper names share the same default role - the one marked by $\alpha$ - with the default case of adjectives, participles, and numerals being 0 .

Figure 11 shows the forward-looking rules activated when the token in question is a noun, a proper name, or a plural adjective or participle. The root of the tree is the POS-tag of the given word. The edges on the first level of the tree contain information gathered from the first element in the parsing window. As an example, if the first token in the window contains the tag of a postposition (Post), the algorithm assigns the tag 0 to the word in question, deleting its original Nom tag. The edges on the second level contain information seen on the second element in the parsing 
window. These edges are only activated if no final decision could be made based on the first token in the window and only a default tag was assigned to the given token.

A special distinction is made during the process not visible on the decision trees. If the given word has a possessive case suffix on it, no Gen tag can be assigned to it based on a possessive suffix on the second element in the window. It is a simplification with which we intend to rule out cases like (4a). The genitive case of a word like the one in bold in (4b) remain identifiable for the algorithm by detecting the possessive suffix on the first element in the window (megbizásából ('on behalf of the government')).

(4)
a. Magyarorszá
mostani nyilatkozat-á-ból
Hungary
government-Poss.3sG
current statement-Poss.3sG-out.of
N.Nom N.Poss.3sg.Nom
Adj.Nom N.Poss.3sg.Ela
'from the current statement of the government of Hungary'
b. Magyarország kormány-a nyilatkozat-á-ból
Hungary government-Poss.3sg statement-Poss.3sG-out.of N.Nom N.Poss.3sg.Nom N.Poss.3sg.ElA
'from the statement of the government of Hungary'
The rules for singular adjectives and participles are displayed in Figure 2. The same distinction explained above is valid for the analysis of these tokens as well. Finally, the rules for numerals can be seen in Figure 3. Throughout the figures we use the macro NPMod for adjectives and participles as nom-or-gen started to tag every adjective and participle as NPMod referring to their ability to modify an NP.
The algorithm implemented in Python is available with the test corpus containing the gold standard annotation at https://github.com/ppke-nlpg/nom-or-not.

\section{Results}

For the evaluation of the performance of the algorithm we used a randomly composed subcorpus of the Hungarian Gigaword Corpus. The test corpus contains 500 sentences with no restriction to genre, content or quality. We carried out the morphological analysis of the sentences with the emMorph tool integrated in e-magyar language processing system (Váradi et al. (2018)).

The testcorpus contains 2255 tokens tagged as Nom by the morphological analyser. We manually annotated them with tags from the set described above. The output of the algorithm was compared to this gold standard. It is important to note that the human annotation took the whole sentence into consideration and no default tags were allowed (unless the whole sentence was ambiguous). As the algorithm operates without analysing the whole sentence, it necessarily provides ambiguous responses in some cases meaning that we cannot expect $100 \%$ recall. The algorithm was consciously designed to work with high precision instead of high recall.

The evaluation follows the rules described in Table 1. The true positive (TP) matches are the correct ones. The erroneous or overspecified results are considered false positives (FP). Finally, we refer to the uncertain (underspecified) responses of the algorithm as false negatives (FN). The results are shown in Table 2. By precision we mean the percentage of $T P /(T P+F P)$ and by recall we mean $T P /(T P+F P+$ $F N)$. 


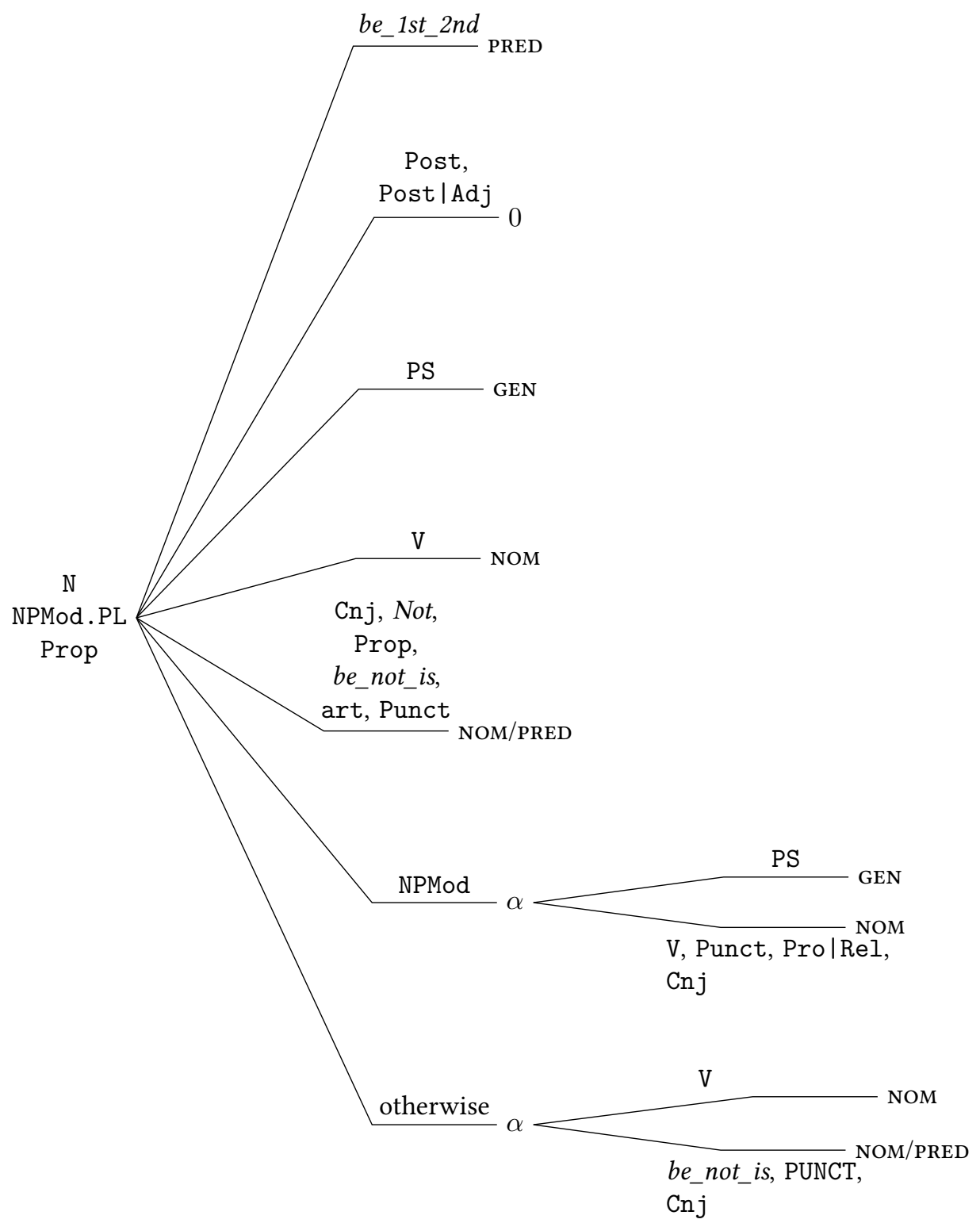

Figure 1: Decision tree summarising the rules concerning nouns, proper names, and plural adjectives, numerals and participles. The root of the tree is the POS-tag of the token under examination. The edges on the first level contain information seen on the first element in the parsing window. The edges on the second level contain information seen on the second element in the parsing window. be_1st_2nd is a macro for the 1st and 2nd person forms of the copula. Not is a macro for negation. be_not_is is a macro for any copula except for the singular and plural 3rd person form of $b e$.

As can be seen, the algorithm achieved moderately good recall and a precision lower than expected. We analysed the results in more detail in a confusion matrix (Table 3). The rows display the responses of the algorithm, while the columns show 


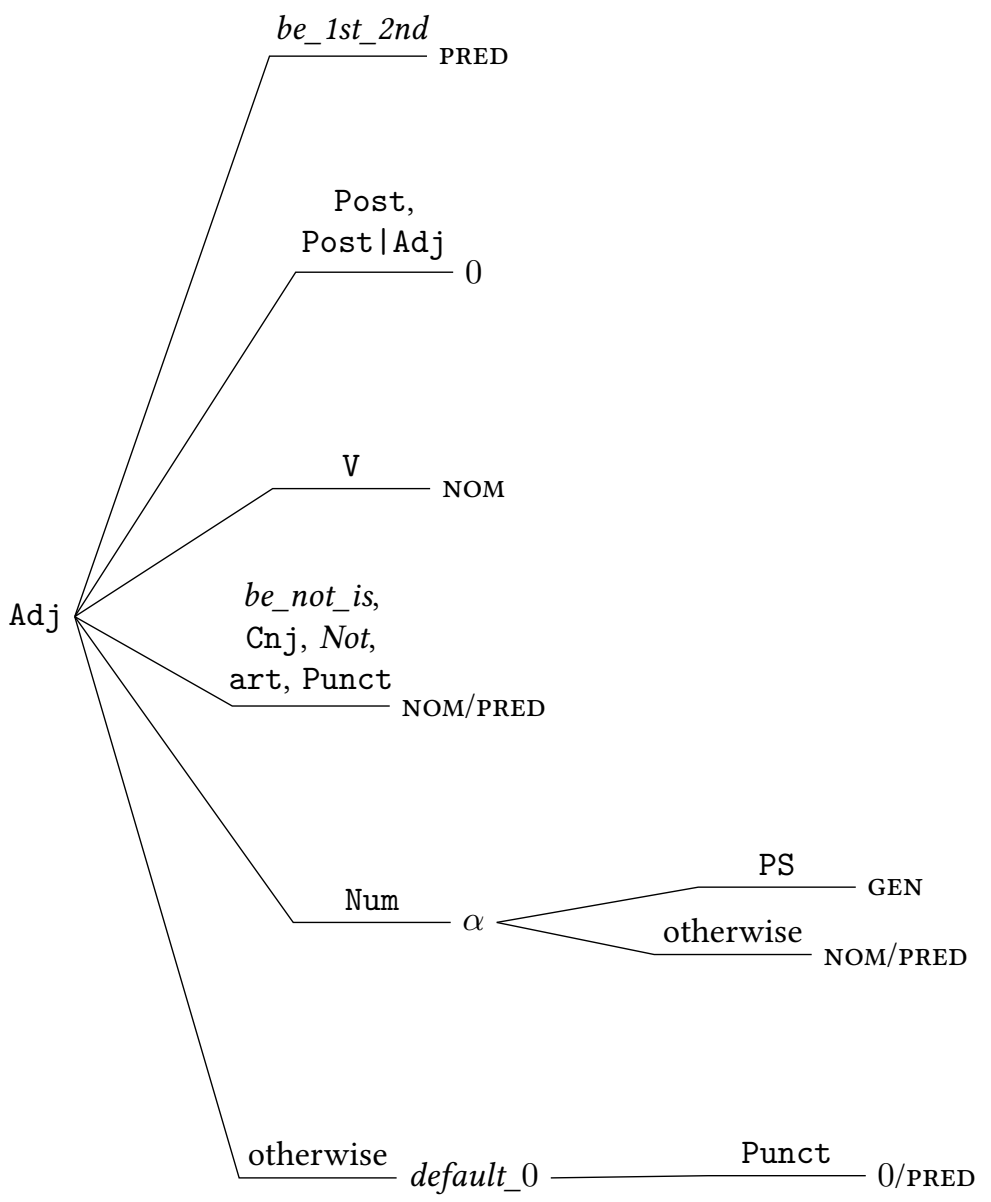

Figure 2: Decision tree summarising the rules concerning (singular) adjectives and participles. The root of the tree is the POS-tag of the token under examination. The edges on the first level contain information seen on the first element in the parsing window. The edges on the second level contain information seen on the second element in the parsing window. be_1st_2nd is a macro for the 1st and 2nd person forms of the copula. Not is a macro for negation. be_not_is is a macro for any copula except for the singular and plural 3rd person form of $b e$.

the gold standard annotation.

A significant part of the errors (102) is due to an erroneous morphological annotation of the surrounding tokens. We eliminated those from the final results.

\section{Discussion}

As expected, the algorithm performs with a moderately high recall compared to that of nom-or-what (67.63\%) which is due to the fact that some of the default tags were eliminated from the algorithm. Recall is influenced by the number of false negative hits (361 in the results). Considering that the algorithm does not have the whole sentence available when deciding, underspecification (resulting in false negative hits) 


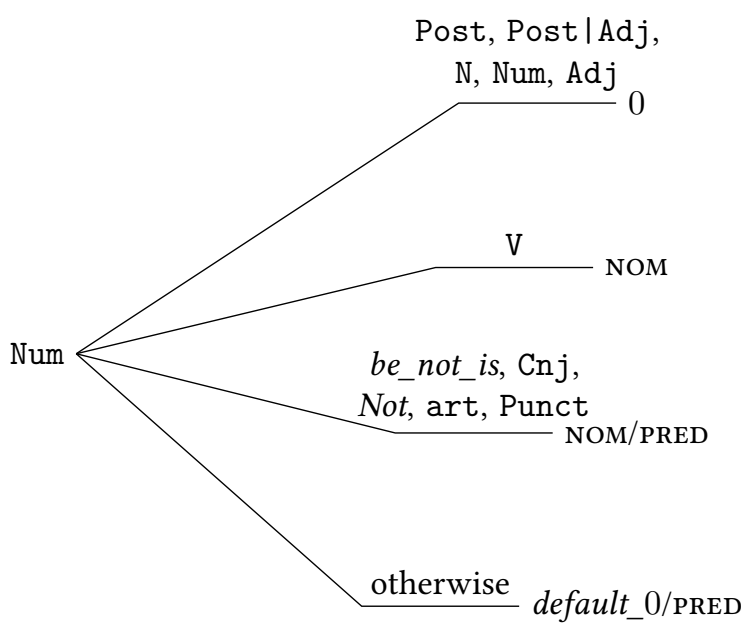

Figure 3: Decision tree summarising the rules concerning numerals. The root of the tree is the POS-tag of the token under examination. The edges on the first level contain information seen on the first element in the parsing window. be_not_is is a macro for any copula except for the singular and plural 3rd person form of $b e$.

\begin{tabular}{|ccc|}
\hline category & result & standard \\
\hline \multirow{4}{*}{ TP } & NOM & NOM \\
& GEN & GEN \\
& PRED & PRED \\
& 0 & 0 \\
& vOC & vOC \\
& $\alpha$ & $\alpha$ \\
\hline \multirow{4}{*}{ FP } & NOM & $\alpha$ \\
& GEN & $\alpha$ \\
& 0 & $0 /$ PRED \\
& PRED & NOPED \\
& NOM & NOM/PRED \\
& PRED & NOM/PRED \\
& every other non-matching tags \\
\hline \multirow{4}{*}{ FN } & $\alpha$ & NOM \\
& $\alpha$ & GEN \\
& $0 /$ PRED & 0 \\
& $0 /$ PRED & PRED \\
& Nom/Pred & Nom \\
& NOM/PRED & PRED \\
\hline
\end{tabular}

Table 1: Rules of evaluation. The tags in the result column are the ones assigned by the algorithm. The tags in the standard column are the gold standard annotation.

is comprehensible in many of the cases. These results are not as problematic for the whole parsing task as the false positive ones, since the uncertain tags can still be specified at a later point of parsing with the scanning of further words. 


\begin{tabular}{|ccc|}
\hline Precision & Recall & F-measure \\
\hline $77.82 \%$ & $79.3 \%$ & $78.55 \%$ \\
\hline
\end{tabular}

Table 2: Test results of the nom-or-not algorithm evaluated on 500 randomly selected and manually annotated sentences

\begin{tabular}{|c|ccccccc|}
\hline & Nom & Gen & 0 & Pred & Voc & $\alpha$ & Nom/Pred \\
\hline Nom & 281 & 9 & 54 & 57 & 0 & 0 & 0 \\
Gen & 3 & 229 & 8 & 0 & 0 & 0 & 0 \\
0 & 1 & 1 & 811 & 3 & 0 & 0 & 0 \\
Pred & 105 & 0 & 2 & 62 & 0 & 0 & 5 \\
Voc & 0 & 0 & 0 & 0 & 0 & 0 & 0 \\
alpha & 83 & 27 & 79 & 5 & 0 & 0 & 0 \\
Nom/Pred & 143 & 2 & 26 & 69 & 1 & 1 & 0 \\
0/Pred & 0 & 0 & 39 & 0 & 0 & 0 & 0 \\
\hline
\end{tabular}

Table 3: Confusion matrix. The rows refer to the tags assigned by the algorithm. The columns represent the gold standard annotation.

The confusion matrix in Table 3 reveals that the majority of FP hits (268) is in connection with Nom or Pred, and more than half of them (162) is caused by a swap of these two tags. This can be explained on the one hand with the fact that our rules detecting predicative nominals are highly dependent on our preceding decisions on nominals: if a Nom was found we assume that no more Nom should be identified. However, our rules do not take clause boundaries into consideration, although a previously found Nom may be the subject of another clause other than the clause under examination. Stopping the backwards-looking rules on clause boundaries is a rather important issue to solve later. Obviously, any erroneously annotated Nom can lead to further mistakes during the analysis, even within the same clause. On the other hand, transposing Nom with Gen or vice versa is often caused by a verb falsely considered a copular verb. Lehet (may be) or lesz (will be) are just two examples of verbs that can either be a copular verb or a normal verb. This distinction is not available in their current morphological annotation, therefore the algorithm always assumes them to be a copular verb.

Another source of errors (159 cases) is the undiscovered inner structure of constructions like (5a) and (5b). Here we assume that there is no case suffix on the first element, therefore a 0 would be the correct tag for it. However, detecting these names is challenging and currently not solved in nom-or-not. There is no visible sign of the connection between the words in these constructions, especially not in their morphological analysis. Therefore, the first element most often receives a default tag. Presumably, these cases should be referred to a module responsible for world knowledge.

(5) a. elnök úr

president sir

N.Nom N.Nom

'Mr. President' 
b. Kinaesthetics termék

Kinaesthetics product

Prop.Nom N.Nom

'the product Kinaesthetics'

Finally, cases like (6a) present a challenge to our algorithm as well: these are some kind of exclamations without any particular case suffix on them, as they play no role in the sentence. We would assign a 0 tag for them, but their distinction is quite problematic and at the moment unsolved in a sentence.

(6) a. Támadás!

attack

N.Nom

'Attack!'

Setting the unsolved problems and all the errors aside, we can see that the algorithm performs well with genitive case and with tokens not bearing any suffix at all (tagged with 0). With Pred, on the other hand, nom-or-not is quite uncertain, but never assigns any Gen or 0 tag to the nominal predicates of a sentence.

A part of the underspecification (FN results) may be solved by inserting a final step at the end of the analysis of each sentence: any verb following the tokens tagged as Nom/Pred can clarify its role as Nom.

\section{Conclusion}

We presented our rule-based algorithm called nom-or-not designed to disambiguate the role of caseless nominals for Hungarian. It is the successor of some related algorithms, each of which were implemented to solve a small part of the complex problem. Here we intended to provide an algorithm able to deal with every possible role of caseless nominals.

In this paper, we presented the design of the algorithm accompanied by the preliminary results obtained by evaluating the algorithm's performance on a test corpus containing 500 manually annotated sentences. Although we expected a higher precision, the majority of FP results is not a random mistake but a systematic error that can and should be solved by extending our rules or by evaluating the algorithm on a more precisely annotated test corpus. The recall is higher than our expectations proving that eliminating the default tags of adjectives, participles and numerals results in a better performance.

There are numerous tasks ahead of us: we need to revise our rules concerning predicative nominals as they seem to cause a significant amount of FP results. After inserting a final check in the algorithm that makes it able to clarify the role of tokens temporarily annotated with a tag of a default value, nom-or-not will hopefully provide a solution of high precision and recall for this case-disambiguation task for Hungarian. 


\section{References}

Dóra Csendes, János Csirik, Tibor Gyimóthy, and András Kocsor. 2005. The Szeged Treebank. In Václav Matoušek, Pavel Mautner, and Tomáš Pavelka, editors, Text, Speech and Dialogue: 8th International Conference, TSD 2005, Karlovy Vary, Czech Republic, September 12-15, 2005. Proceedings. Springer Berlin Heidelberg, Berlin, Heidelberg, pages 123-131.

Andrea Dömötör. 2018. Nem mind VP, ami állít - A névszói állítmány azonosítása számítógépes elemzőben [All that Predicates is not VP - The Identification of Nominal Predicate in Automatic Parsing]. In Zsófia Ludányi, Valéria Krepsz, and Tekla Etelka Gráczi, editors, Doktoranduszok tanulmányai az alkalmazott nyelvészet köréből 2018. pages 3-10.

Katalin É. Kiss. 2002. The Syntax of Hungarian. Cambridge University Press.

Lyn Frazier and Janet Dean Fodor. 1978. The Sausage Machine: A New Two-stage Parsing Model. Cognition 6(4):291-325.

Francis Roger Higgins. 1973. The Pseudo-Cleft Construction in English. Garland Press, New York.

Noémi Ligeti-Nagy, Noémi Vadász, Andrea Dömötör, and Balázs Indig. 2018. Nulla vagy semmi? Esetegyértelműsítés az ablakban [Zero or Nothing? Case Disambiguation in the Window]. In Veronika Vincze, editor, XIV. Magyar Számítógépes Nyelvészeti Konferencia. pages 25-37.

Attila Novák. 2003. Milyen a jó Humor? [What is Good Humor Like?]. In I. Magyar Számítógépes Nyelvészeti Konferencia. SZTE, Szeged, pages 138-144.

Attila Novák. 2014. A New Form of Humor - Mapping Constraint-Based Computational Morphologies to a Finite-State Representation. In Nicoletta Calzolari, Khalid Choukri, Thierry Declerck, Hrafn Loftsson, Bente Maegaard, Joseph Mariani, Asuncion Moreno, Jan Odijk, and Stelios Piperidis, editors, Proceedings of the Ninth International Conference on Language Resources and Evaluation (LREC'14). European Language Resources Association (ELRA), Reykjavik, Iceland.

Attila Novák, Borbála Siklósi, and Csaba Oravecz. 2016. A New Integrated Opensource Morphological Analyzer for Hungarian. In Nicoletta Calzolari, Khalid Choukri, Thierry Declerck, Sara Goggi, Marko Grobelnik, Bente Maegaard, Joseph Mariani, Helene Mazo, Asuncion Moreno, Jan Odijk, and Stelios Piperidis, editors, Proceedings of the Tenth International Conference on Language Resources and Evaluation (LREC 2016). European Language Resources Association (ELRA), Paris, France.

Csaba Oravecz, Tamás Váradi, and Bálint Sass. 2014. The Hungarian Gigaword Corpus. In Nicoletta Calzolari (Conference Chair), Khalid Choukri, Thierry Declerck, Hrafn Loftsson, Bente Maegaard, Joseph Mariani, Asuncion Moreno, Jan Odijk, and Stelios Piperidis, editors, Proceedings of the Ninth International Conference on Language Resources and Evaluation (LREC'14). European Language Resources Association (ELRA), Reykjavik, Iceland.

Gábor Prószéky and Balázs Indig. 2015. Magyar szövegek pszicholingvisztikai indíttatású elemzése számítógéppel [Psycholingvistically Motivated Analysis of Hungarian Texts with Computer]. Alkalmazott Nyelvtudomány 15(1-2):29-44. Original document in Hungarian. 
Gábor Prószéky, Balázs Indig, and Noémi Vadász. 2016. Performanciaalapú elemző magyar szövegek számítógépes megértéséhez [A Performance-based Parser to the Comprehensive Understanding of Hungarian Texts]. In Kas Bence, editor, "Szavad ne feledd!”: Tanulmányok Bánréti Zoltán tiszteletére, MTA Nyelvtudományi Intézet, Budapest, pages 223-232. Original document in Hungarian.

Leon Stassen. 1994. Typology Versus Mythology: The Case of the Zero-Copula. Nordic fournal of Linguistics 17(2):105-126.

Tibor Szécsényi. 2000. Esetegyeztetés a predikatív fonnévi csoportban [Case agreement in the predicative noun phrase]. In László Büky and Márta Maleczki, editors, A mai magyar nyelv leírásának újabb módszerei IV., Szegedi Tudományegyetem, Szeged, pages $189-202$.

Noémi Vadász and Balázs Indig. 2018. A birtokos esete az ablakkal [Possessor's Case with the Window]. In György Scheibl, editor, LingDok: Nyelvész-doktoranduszok dolgozatai 17., SZTE Nyelvtudományi Doktori Iskola, Szeged, pages 85-99.

Tamás Váradi, Eszter Simon, Bálint Sass, Iván Mittelholcz, Attila Novák, Balázs Indig, Richárd Farkas, and Veronika Vincze. 2018. E-magyar - A Digital Language Processing System. In Nicoletta Calzolari (Conference chair), Khalid Choukri, Christopher Cieri, Thierry Declerck, Sara Goggi, Koiti Hasida, Hitoshi Isahara, Bente Maegaard, Joseph Mariani, Hélène Mazo, Asuncion Moreno, Jan Odijk, Stelios Piperidis, and Takenobu Tokunaga, editors, Proceedings of the Eleventh International Conference on Language Resources and Evaluation (LREC 2018). European Language Resources Association (ELRA), Miyazaki, Japan. 